\title{
MODEL PENAFSIRAN KONTEMPORER
}

Prinsip Hermeneutik dalam Tafsir Al-Qur`ān Al-Hadìth Karya M. Izzat Darwazat

\author{
Ahmad Mustofa \\ STAI ALHUSAIN Magelang \\ mustofa.ahmad8@gmail.com
}

\begin{abstract}
There are two terms in the study of al-Qur'an exegesis, namely mä hawla alQur'ān and mā fì al-Qur'ān. The first term refers to the discussion of the Qur'an with an emphasis on the socio-historical and anthropological aspects of Arab society at the time of the revelation of the Qur'an. Meanwhile, the second term refers to an effort to extract the true meaning of each word and even each letter in the Qur'an. The second form of study is usually in the form of interpretive works, then the first one is more in the form of new principles and methods used in interpreting, or it can even be in the form of criticism of models, systematics and classical interpretation methods. In this simple study, we will dig and explore the thoughts of one of the leading contemporary Muslim scholars who was able to study the two regions simultaneously, namely M. Izzat Darwazat. Through his book al-Tafsìr al-Hadìth, M. Izzat Darwazat has popularized a model for composing the exegesis book by using the tartī al-nuzül system (according to the order in which the sürah al-Qur'an is descended) and has introduced the method of interpreting the Qur'an by using hermeneutic principles.
\end{abstract}

Keywords; M. Izzat Darwazat, al-Tafsìr al-Hadīth, tartīb al-nuzīl and Hermeneutics.

\begin{abstract}
Abstrak
Ada dua istilah dalam kajian tafsir al-Qur`an, yaitu mā hawla al-Qur 'ān dan $m \bar{a} f i$ al-Qur'ān. Istilah yang pertama merujuk pada pembahasan al-Qur'an dengan titik tekan pada aspek sosio-historis dan antropologis masyarakat Arab pada masa turunnya al-Qur'an. Sedangkan istilah yang kedua merujuk pada upaya penggalian makna sejati dari setiap kata bahkan setiap huruf di dalam al-Qur`an. Jika bentuk kajian kedua ini biasanya berupa karya tafsir, maka bentuk kajian yang pertama lebih banyak berupa prinsip dan metode baru yang digunakan dalam menafsirkan, atau bahkan bisa berupa kritik terhadap model, sistematika dan metode penafsiran klasik. Dalam studi yang sederhana ini, kita akan menggali dan mengeksplorasi pemikiran salah satu sarjana muslim kontemporer terkemuka yang mampu melakukan kajian terhadap kedua wilayah tersebut secara bersamaan, yaitu M. Izzat Darwazat. Lewat kitab alTafsìr al-Hadìth-nya, M. Izzat Darwazat mempopulerkan sebuah model penyusunan kitab tafsir dengan menggunakan sistematika tartīb al-nuzūl (sesuai urutan turunnya sūrah al-Qur`an) serta mengenalkan metode penafsiran al-Qur`an dengan menggunakan prinsip-prinsip hermeneutika.
\end{abstract}

Kata Kunci; M. Izzat Darwazat, al-Tafsìr al-Hadìth,tartīb al-nuzūl dan Hermeneutika. 


\section{A. Pendahuluan}

Beberapa tahun yang lalu, dalam sebuah kesempatan, secara tidak sengaja penulis mendapatkan satu set kitab tafsir lungsuran (bekas) sebanyak 12 juz. Secara jelas tertera judul kitab tafsir tersebut yaitu al-Tafsìr al-Hadìth. Sekilas dalam benak penulis, kitab tafsir tersebut adalah sebuah kitab yang ditafsirkan berdasarkan Hadis Nabi Șallāhu Alayhi Wasallam, karena itu namanya adalah al-Tafsìr al-Hadìth.Namun, ketika beberapa juz dari kitab tafsir tersebut penulis buka secara acak, sama sekali penafsiran demi penafsiran dalam kitab tafsir tersebut tak pernah menyinggung Hadis Nabi Ṣallāhu Alayhi Wasallam. Kemudian ketika membaca nama penulisnya pun (dalam huruf Arab tertulis محمد عزة دروزة masih terasa asing kala itu. Sehingga saat itu, karena penulis menganggap kitab tafsir tersebut tidak populer, sulit dimengerti dengan sistematika penulisan yang membingungkan, ${ }^{1}$ maka kitab tafsir sebanyak 12 juz itupun berakhir sebagai hiasan di rak buku.

Namun beberapa waktu lalu, dalam sebuah perkuliahan yang diampu oleh Sahiron Syansuddin, nama M. Izzat Darwazat diangkat dan dijadikan sebagai salah satu topik bahasan selama perkuliahan berlangsung. Saat itulah, penulis baru menyadari bahwa M. Izzat Darwazat merupakan salah satu tokoh tafsir kontemporer ${ }^{2}$ sekaligus pioner dalam menerapkan prinsip hermeneutik dalam proses penafsiran, sedangkan kitab al-Tafsìr alHadīth merupakan karya monumentalnya di bidang tafsir al-Qur`an dengan menerapkan prinsip-prinsip hermeneutika di dalamnya. Dalam penelaahan lebih lanjut, tafsir karya ini terasa sangat istimewa sebab selain penulisnya merupakan warga asli Palestina dan menjadi bagian dari sejarah wilayah sengketa serta ditulis saat ia dipenjara karena perjuangannya dalam kemerdekaan Palestina, posisi M. Izzat Darwazat memiliki kekhususan dibandingkan dengan sarjana muslim kontemporer lainnya, semisal Fazlurrahman, Arkoun, Syahrur, Nasr Hamid Abu Zaid-, yaitu, melakukan kritik terhadap rancang bangun epistimologi dan metodologi penafsiran (البحث ما حول القران) terutama khazanah tafsir klasik, sekaligus ia juga

\footnotetext{
${ }^{1}$ Kebingungan penulis karena sistematika penyusunan surat yang ditafsirkan bukan berdasarkan tartib mushafi sebagaimana lazimnya tafsir populer, melainkan penafsiran terhadap surah-surah dalam al-Qur`an tersebut berdasarkan tartīb nuzūli.

${ }^{2}$ Yang dimaksud istilah kontemporer di sini adalah tafsir yang ditulis antara akhir abad 19 sampai dengan abad 21. Lihat dan bandingkan dengan Ahmad Syukri, Metodologi Tafsir al-Qur'an Kontemporer dalam Pandangan Fazlurrahman (Jambi: Sulthan Thaha Press, 2007), 43. Namun ada juga pendapat yang lebih populer mengatakan bahwa era kontemporer itu dimulai semenjak kekalahan tiga negara Arab dalam perang enam hari melawan Israel tahun 1967. Oleh karena itu, istilah tafsir kontemporer yaitu tafsir yang lahir pada sekitar tahun tersebut.
} 

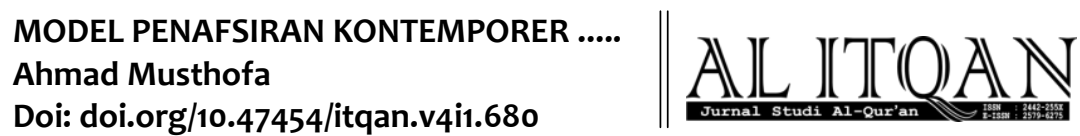

sumbut (bahasa Jawa: sepadan) dengan menghasilkan karya tafsir ( البحث ما في القران) lengkap dengan tawaran metodologi penafsirannya.

Apa yang penulis alami dalam paragraf di atas, sebetulnya merupakan contoh kecil saja dari minimnya kajian tafsir di Indonesia terutama yang berkaitan dengan pembahasan terhadap kitab tafsir kontemporer berikut dengan tawaran metodologi penafsirannya. ${ }^{3}$ Hal ini tentu saja menjadi pekerjaan rumah yang tidak ringan bagi para sarjana muslim wa bi alkhuṣūs sarjana tafsir di Indonesia untuk lebih giat lagi dalam mengenalkan karya-karya tafsir kontemporer baik dalam kajian akademik maupun non akademik, sebab kajian tafsir kontemporer sangat dibutuhkan guna merespon perkembangan zaman serta kemajua ilmu pengetahuan dan tekhnologi, tanpa harus kehilangan nilai-nilai dan prinsip dasar ușüluddìn. Oleh karena itulah, penulisan artikel yang bertemakan penafsiran kontemporernya M. Izzat Darwazat ini merupakan bagian dari ikhtiyār penulis guna merespon kebutuhan tersebut.

\section{B. Rumusan Masalah dan Tujuan Penelitian}

Berangkat dari latar belakang di atas, maka problem akademik yang akan penulis gali dalam penelitian ini berkaitan erat dengan riwayat hidup M. Izzat Darwazat dan latar belakang penulisan kitab al-Tafsì al-Hadith serta sistematika dan metode hermenutika yang digunakan oleh Izzat dalam menulis kitab tafsir tersebut. Diharapkan dari problem akademik tersebut, penulis bisa mengungkap keterhubungan antara situasi dan kondisi sosio-politik yang melatarbelakangi penulisan kitab al-Tafsīr al-Hadīth (terutama kondisi sosio-politik di kawasan konflik yaitu Palestina dan Syiria secara khusus serta kawasan Timur Tengah pada umumnya) dengan penerapan prinsip-prinsip hermeneutika sebagai pilihan metode dalam menafsirkan al-Qur`an dan sistematika tartīb muṣhafy dalam penulisan kitab tafsirnya tersebut.

\section{Metode Penelitian dan Kerangka Teori}

Penelitian tentang kitab al-Tafsìr al-Hadìth karya M. Izzat Darwazat ini merupakan penelitian kualitatif dan bukan penelitian lapangan. Oleh karena itu, penulis lebih banyak mencari data-data, baik tentang M. Izzat Darwazat maupun kitab tafsirnya, lewat kepustakaan

\footnotetext{
3 Ciri dari bangunan epistemologi tafsir kontemporer adalah pembacaan kritis terhadap tradisi dan modernitas sebelum mempertemukan keduanya dalam rangka menjawab tantangan dan problematika kontemporer. Bangunan epistem inilah yang membedakan dengan mazhab tradisional (turāth) yang cenderung apriori dalam menyikapi modernitas demi konservasi tradisi. Sebaliknya mazhab modern (hadatsah) berpandangan bahwa tradisi sebagai suatu hambatan dalam mencapai kemajuan (modern) oleh karena tradisi harus dibuang. lihatMukhrij Sidqy dalam Urgensi Tafsir Kontemporer, https://artikula.id/mukhrij/urgensi-tafsir-kontemporer)
} 
dalam bentuk buku, jurnal penelitian maupun paperpenelitian yang telah diseminarkan. Karena fokus dalam penelitian ini adalah karya M. Izzat Darwazat, yaitu kitab al-Tafsīr alHadìth, maka kitab tersebut mejadi sumber primer dalam penelitian ini. Data yang berasal dari sumber lain, akan diposisikan sebagai sumber sekunder guna melengkapi kebutuhan data dan informasi kitab al-Tafsīr al-Hadīth. Karena salah satu tujuan dari penelitian ini, selain untuk membahas prinsip-prinsip hermmeneutika yang digunakan oleh Darwazat sebagai metode penafsiran dalam kitab tafsirnya, juga akan mengungkap latar belakang dan kondisi sosio-politik sebagai aspek yang paling berpengaruh terhadap cara berpikir Darwazat, maka penelitian ini bersifat eksploratif, yaitu suatu desain penelitian yang bertujuan untuk melakukan mapping suatu objek (yang dalam penelitian ini adalah kitab tafsirnya M. Izzat Darwazat yaitu al-Tafsìr al-Hadìth) secara mendalam di mana publik belum mengetahui secara persis dan spesifik mengenai objek penelitian tersebut. ${ }^{4}$

\section{Biografi Intelektual M. Izzat Darwazat}

\section{Riwayat Hidup}

Muhammad 'Izzat Darwazat (1888-1984 M) adalah salah seorang mufassir berkebangsaan Palestina. Awalnya ia dikenal sebagai seorang sejarawan. Namun, ketika ia dipenjara oleh Perancis, ia mulai menekuni al-Qur'an dan tafsir. Di dalam penjara, ia berhasil menulis trilogi pengantar tafsirnya, yaitu al-Tafsìr al-Hadìth. Satu hal yang cukup menarik dari karya tafsir ini adalah dari aspek intertekstualitasnya, yaitu usaha membandingkan teks al-Qur'an dengan kitab kitab suci sebelumnya, yaitu Taurat dan Injil. Maka tak heran, jika membaca tafsir ini, akan banyak kutipan yang bersumber dari Alkitab (Bibel). ${ }^{5}$

Darwazat menuliskan tafsir al-Qur`annya selama penahanannya di penjara Damaskus yang dijatuhkan oleh penguasa militer Inggris pada PD I, ketik terjadi aksi perlawanan rakyat terhadap pemerintahan kolonial Inggris di Palestina. Meski Inggris dapat menumpas perlawanan rakyat Palestina pada 1936 dan mematahkan aktivitas dan karier politik Darwazat. Namun pemenjaraannya di Damaskus merupakan awal kehidupan barunya, di mana al-Qur`an menjadi perhatian utamanya saat itu. Pada kesempatan itu juga, ia memanfaatkan "kesempatan" itu dengan berbagai aktivitas religius dan mulai membaca buku apa saja

\footnotetext{
4 Suharsimi Arikunto, ProsedurPenelitian; Suatu Pendekatan Praktik (Jakarta: Rineka Cipta, 2014), 14.

5 Leni Lestari, "Menstrual Taboo dan Kontrol Sosial Perempuan Menurut Muhammad 'IzzahDarwazat: Studi Intertekstualitas Terhadap Al-Qur'an dan Bibel”, Jurnal Suhuf, Vol. 8, No. 2, (Juni 2015), 362.
} 

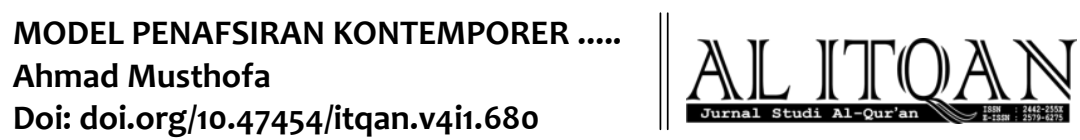

tentang tafsir dan studi al-Qur`an yang dapat diakses. Selama masa penahanan itulah ia menyelesaikan tiga karyanya tentang al-Qur`an. ${ }^{6}$

Ide menulis tafsir modern (kemudian istilah tafsir modern tersebut diabadikan sebagai judul karya tafsirnya dalam bahasa Arab, yaitu al-Tafsìr al-Hadīth) dimulai setelah ia menyelesaikan tiga karya tersebut di dalam penjara Damaskus. Sebab, setelah masa penahanannya di Damaskus telah selesai, ia tetap tak boleh pulang ke Nablus karena penguasa Inggris menahannya. Kemudian Darwazat diberangkatkan ke Turki dan tinggal di sana hingga akhir 1945. Di Turki, ia memanfaatkan waktu untuk bergelut dengan berbagai buku, karya ilmiah dan artikel-artikel ilmiah untuk merealisasikan angannya menulis sebuah tafsir modern. Draft kasar dari tafsir modern tersebut diselesaikan di Bursa, setelah itu ia menulis volume lain berjudul al-Qurān al-Majīd sebagai pengantar tafsir modernnya. Dalam karya terakhirnya inilah ia menjelaskan metode tafsirnya dengan suatu istilah yang disebutnya sebagai exemplary method atau metodologi percontohan.

Sebagai warga Palestina, ia menjadi salah satu orang yang secara aktif menjadi anggota masyarakat nasionalis Arab (members of Arab Nasionalist Societes) tahun 19091918, mewakili organisasi al-Fatāt (Young Arab Societis). ${ }^{7}$ Sebagai penghargaan terhadap kontribusinya di bidang keilmuan tafsir, ia pun disejajarkan dengan beberapa penulis progresif kritis (seperti Umar Abū al-Nașr dan Umar Farrukh) di kalangan bangsa Arab, yang mencoba menghadirkan kajian sejarah secara kritis, bukan lagi kajian sejarah namun berisikan kajian yang masih bersifat teologis. ${ }^{8}$

\section{Sistematika Penyusunan Kitab al-Tafsīr al-Hadīth}

Hampir seluruh kitab tafsir klasik (semisal tafsir al-Tabarī, tafsir Ibn Kathīr, tafsir alZamakhshari dan lainnya) disusun menggunakan metode taḥlìli. ${ }^{9}$ Dalam pandangan Hasan Hanafi,metode tạ̣līlì ini dapat memberikan berbagai informasi tentang teks, sejarah, linguistik dan kondisi sosial. Ia menawarkan banyak pengetahuan dan membuat kesadaran

\footnotetext{
${ }^{6}$ Ismail K Poonawala, Muhammad'Izzat Darwazat's Principles of Modern Exegesis; A Contribution Toward Qur'anic Hermeneutics, in APPROACH TO THE QUR'AN, edited by GR Hawting and Abdul Kader A Shareef (New York: Routledge, 1993), 126 - 127.

7 Muhammad Muslih, "Arab Politics and the Rise of Palestinian Nationalism", Journal of Palestine Studies, Vol. 16, No. 4 (Summer, 1987), 81.

${ }^{8}$ Nabih Amin Faris, "The Arabs And Their Story", MIDLE EAST JOURNAL VOL. 8, No 2 (Spring; 1954), 157.

9 Menafsirkan al-Qur`an ayat demi ayat secaa beruntun (mulai dari penafsiran surat al-fatihah sampai dengan surat an-nas), berdasarkan susunan surat al-Quran mușhaf uthmāni yang diyakini bersumber dari ketetapan Nabi Muhammad SAW (tawqïfi).
} 


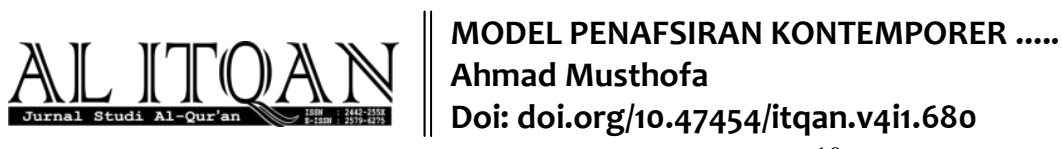

menjadi lebih mengetahui kondisi obyektif teks. ${ }^{10}$ Dengan mengikuti susunan tradisional teks al-Qur`an ternyata juga memiliki hikmah tersendiri, yaitu dengan berpadunya berbagai jenis sastra dalam bentuk narasi, perintah, ancaman dan janji. Al-Qur`an bukan hanya buku pengetahuan, tetapi juga keyakinan. Al-Qur`an tak hanya cocok untuk akal, namun juga sesuai untuk perasaan, ia tak hanya menawarkan teori, namun juga memotivasi aksi. Metode taḥlīlì juga membantu siapapun untuk mengetahui mentalitas para mufassir klasik dan referensi pengetahuan, sejarah dan tingkat pemahaman mereka, mengingat semua tafsir bersifat historis. ${ }^{11}$

Di saat yang sama, ada beberapa kelemahan mendasar pada metode tạ̣līlì ini. Hasan Hanafi mensinyalir paing tidak ada tiga kelemahan mendasar, yaitu: ${ }^{12}$

a. Keterputusan tema yang sama dalam berbagai surat, sehingga tema lainnya potensial memutuskan kesatuan tema sebelumnya, seperti keadilan, kekuasaan, manusia, akal, insting, individualitas, solidaritas sosial dan lain-lain.

b. Mengulang tema yang sama tanpa adanya kesatuan makna untuk membangun konsep tema makro seperti misal status perempuan yang beberapa kali dibahas dalam berbagai ayat / surat al-Qur`an. Hal ini mengakibatkan pengungkapan makna terhadap suatu tema menjadi kurang maksimal.

c. Metode tahlìlī yang biasanya dalam format berjilid-jilid menyebabkan kesulitan dalam pembacaan dan pendalaman. Pembaca seringkali bingung berhadapan dengan informasi yang banyak dan bercampur aduk.

d. Mengaburkan antara informasi dan pengetahuan, kadang-kadang para mufassir memberikan informasi padahal al-Qur`an sedang memberikan pengetahuan. Seperti yang kita ketahui, informasi merupakan sesuatu yang telah diketahui dan dikomunikasikan dari suatu sumber ke sumber lain, sementara itu pengetahuan adalah sesuatu yang baru atau tambahan terhadap sebuah informasi.

Seiring perjalanan waktu, para mufassirgenerasi berikutnya berupaya untuk melakukan "ijtihad-ijtihad keilmuan" guna melengkapi berbagai kekurangan-kekurangan yang ada pada kitab-kitab tafsir klasik, baik dari sisi sistematika penyusunan tafsir maupun

\footnotetext{
${ }^{10}$ Hassan Hanafi, "Dari Teks ke Aksi; Merekomendasikan Tafsir Tematik", jurnal STUDI QUR`AN, Vol. 1, (Januari 2006), 57.

${ }^{11}$ Ibid.,, 58.

${ }^{12}$ Ibid.,, 58-59.
}

76 AL-ITQAN,Volume 4, No. 1, 2018 

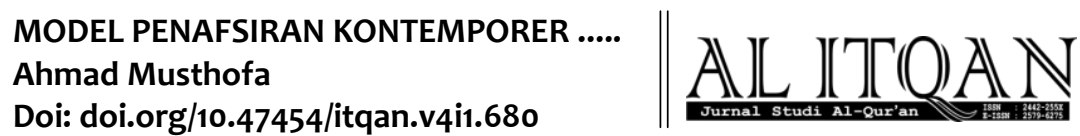

metode dan pendekatan yang digunakan dalam menafsirkan sebuah ayat al-Qur`an. M. Izzat Darwazat adalah satu diantara para mufassir yang melakukan ijtihad tersebut.

M. Izzat Darwazat sendiri, yang selain seorang mufassir, juga seorang sejarawan dan ahli politik. Namanya di kalangan akademisi kususnya kajian tafsir di Indonesia, masih belum terlalu familiar, padahal boleh dibilang Darwazatlah yang merintis penulisan tafsir 30 juz dengan menggunakan pendekatan interteks pada sekitar tahun 1962, sebuah tafsir yang berbasiskan pemahaman antar teks, yaitu teks tertentu harus dikaitkan dengan teks-teks lain, sehingga semuanya harus dilibatkan dalam proses penafsiran. ${ }^{13}$ Sebuah pendekatan yang belakangan ini banyak diaplikasikan sebagai sebuah pendekatan ilmiah. ${ }^{14}$

Kitab al-Tafsìr al-Hadìthkarya M. Izzat Darwazat ini terdiri dari 12 jilid. Disusun berdasarkan tartīb nuzüuly, yaitu dengan menempatkan surat al-'alaq sebagai surat pertama yang ditafsirkan, kemudian setelah itu berturut-turut menempatkan surat al-Qalām, alMuzzammil, al-muddathir, al-Fātihaha, al-Masad (al-Lahab), al-Takwīr, al-A'lādan seterusnya sampai dengan akhir surat Makiyyahyaitu surat al-Muṭaffifin. Kemudian dilanjutkan dengan menafsirkan surat al-Baqārah sebagai surat yang pertama kali diturunkan di Madinah, disusul secara berurutan oleh surat al-Anfāl, Āli 'Imrān, al-Aḥzāb, al-Mumtaḥanahdan seterusnya sampai dengan surat terakhir yang dikategorikan sebagai Madaniyyah yaitu surat al-Nașr. ${ }^{15}$

Dalam pandangan Darwazat, dengan menggunakan sistematika tartīb nuzūly ini pembaca tafsir akan lebih mudah dalam memahami ayat-ayat al-Qur`an, sebab dengannya para pembaca secara otomatis akan mengikuti perjalanan sejarah Nabi Muhammad dari waktu ke waktu, pembaca diajak bergabung dalam suasana proses pewahyuan al-Qur`an dan masuk dalam dimensi ruang dan waktu saat terajadinya proses pewahyuan, sehingga secara sadar akan menemukan hikmah di balik proses dan tahapan pewahyuan al-Qur`an. ${ }^{16}$ Dia menyimpulkan bahwa tafsir harus dibedakan dengan mushaf yang menurutnya telah diformat sebagai media untuk dibaca (li al-tilāwah) dan karenanya musḥafmerupakan cabang ( $f \bar{a} n$ ) keilmuan tersendiri yang berbeda dengan tafsir. Tafsir, menurutnya, adalah sebuah tindakan ( $a m l$ ) yang berdiri sendiri, tak ada kaitanya dengan urutan mushafy. ${ }^{17}$ Ia berharap bahwa

\footnotetext{
13 Dibahas pada sub bab tentang konsep penafsiran al-Qur 'an yufassiru ba'dluhum ba'dla.

14 Lenni Lestari, "Pendekatan Intertekstualitas Perspektif Muhammad 'Izzah Darwazat; Sebuah Kontribusi Dalam Menghadapi Masyarakat Multikultural”, Jurnal AT-TAFKIR Vol. VII No. 2 (Desember 2014),28.

15 Muhammad 'Izzah Darwazat, al-Tafsīr al-Hadīth: al-Suwar Murattabatun Hasba al-Nuzūl (Damaskus: Dār Ihyā' al-Kutub al-'Arabiyyah, 1960,) I:8.

${ }^{16}$ Ibid.

${ }^{17}$ Ibid., 9.
} 
karya tafsirnya ini bisa merespon kebutuhan mendesak generasi muda, yang mengeluhkan gaya tradisional tafsir, sehingga banyak di antara generasi muda yang telah meninggalkan tafsir-tafsir tradisional tersebut, yang pada gilirannya berakibat pada terputusnya hubungan dengan al-Qur`an, kitab suci yang ditafsirkan. ${ }^{18}$

Sedangkan sumber penafsiran yang digunakan oleh Darwazat, adalah sumber utama, yaitu penafsiran bi al-ma `thūr, yaitu menafsirkan al-Qur`an dengan al-Qur`an, dan al-Hadis karenakeduanya merupakan penjelas al-Qur`an, al-Qur`an dengan riwayatpara sahabat, karena mereka lebih mengetahui waktu turunnya wahyu danperkataan kibār al-tābi'īn karena mereka menerimanya secara langsung dari parasahabat. Kedua adalah penafsiran bi al-ra'yi. Penafsiran ini juga biasa dikenaldengan tafsir bi al-ijtihād. Yang dimaksud dengan penafsiran bi ar-ra'yi atau bi al-ijtihād yaitu penafsiran yang menggunakan penalaran akal. ${ }^{19}$

Selain menggunakan kedua sumber di atas, Darwazat juga merujuk kepada para mufassir baik yang klasik mupun yang modern. Di antara mufassir yang dirujuk tafsirnya oleh Darwazat adalah Tafsir Ibn 'Abbās, Riwayat $A b \bar{u}$ Șāliḥ, Muhammad bin Ismā'īl al-Bukhāri, bab tentang tafsīr dalam Șaḥihh-nya, Tafsir al-Ṭabāri, Tafsir al-Nasafî, Tafsir Abu al-Sa'ūd, Tafsir al-Ṭūsī, Tafsir al-Khāzin, Tafsir al-Rāzi, Tafsir al-Zamakhshari, Tafsir al-Tabarsi,

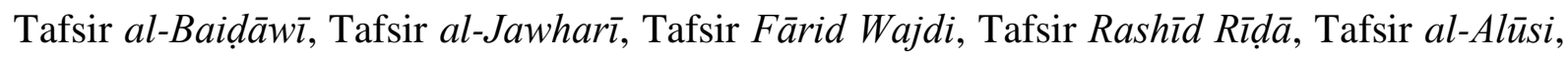
Tafsir Abū Hayyān, Tafsir Ibn Kathīr, Tafsir al-Bagāwī, Tafsir al-Qurțub̄̄, Tafsir al-Marāgī, dan Tafsir al- 'Adilī.

Tafsir-tafsir tersebut dijadikan rujukan oleh Darwazat dalam menafsirkan serta menjelaskan sebab turunnya ayat dan juga dalam menguatkan pendapatnya ketika menentukan letak sebuah surat. Meskipun Darwazat merujuk kepada tafsir-tafsir yang telah disebutkan di atas, ia juga terkadang tidak sejalan dengan pendapat mufassir yang dirujuknya tersebut dalam beberapa permasalahan. Ia menganalisa dan mengkritisi serta memberikan komentar terhadap pendapat mereka. Di samping merujuk pada kitab-kitab tafsir yang disebutkan di atas, ia juga merujuk pada beberapa kitab ulüm al-Qur 'ān seperti al-Itqān karya al-Suyūṭi dalam menelaah susunan kronologi turunnya surat.

\footnotetext{
18 Ismail K. Poonawala, Muhammad 'Izzat Darwazat's Principles of Modern Exegesis; A Contribution Toward Qur'anic Hermeneutics, in APPROACH TO THE QUR`AN, edited by GR Hawting and Abdul KaderA Shareef, 226.

19 Mannā’ al-Qattān, Mabāḥith fì 'Ulūm al-Qur 'ān, 351. Lihat juga Muhammad Hamdi Zaglūl, al- Tafsīr bi alRa yi; Qā'idatuhū wa Dawābituhu wa A'lāmuhu (Damaskus: Maktabah al-Farābī, 1999), 107.

${ }^{20}$ Darwazat, al-Qur'ān al-Majīd, 203.
} 

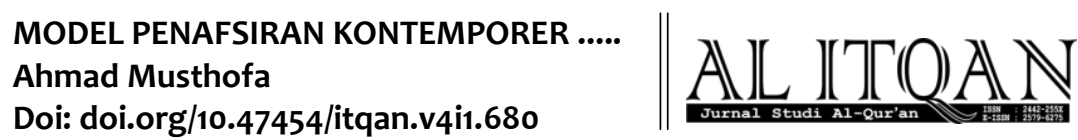

Darwazat juga menggunakan kitab-kitab tārīkh maupun sīrah sebagai rujukan dalam menafsirkan al-Qur’an, semisal Tabaqāt al-Kubrā Li Ibn Sa'd, Sīrah Ibn Hishām, Tārīkh alTabarī, khususnya ketika menjelaskan sejarah hidup Nabi. Hal ini dapat dilihat dalam penafsirannya, semisal ketika menafsirkan surat al-Nașr, khususnya yang berkaitan dengan haji wada' dan kondisi Nabi pada detik-detik terakhirnya. ${ }^{21}$ Bahkan Darwazat juga menggunakan rujukan kitab Perjanjian (Bible) ketika ia menafsirkan ayat-ayat al-Qur`an khususnya yang berhubungan dengan kisah-kisah Nabi ataupun umat terdahulu yang terdapat dalam al-Qur`an dan kitab perjanjian. ${ }^{22}$

\section{E. Prinsip Hermeneutika Dalam Penafsiran M. Izzat Darwazat}

Ada beberapa aspek hermeneutika yang disampaikan oleh Darwazat dalam karya tafsirnya al-Tafsìr al-Hadìth, di antaranya adalah berikut ini:

\section{Al-Usūül (Prinsip / Pokok) dan al-Wasā̄il (Media)}

Secara umum, isi al-Qur`an terdiri dari dua tema besar, yaitu prinsip dasar (al-ușūl) dan alat / media / pelengkap (al-wasāil). Al- uṣūl merupakan esensi karena merupakan tujuan dari pewahyuan dan misi kenabian. Substansi dari pewahyuan al-Qur'an kepada Nabi Muhammad SAW adalah agar manusia menyembah Allah SWT dan mematuhi aturan-aturan yang telah ditetapkan dalam syariat. Selebihnya, semisal sejarah Nabi, 'ibārat, nasehat, balasan di akhirat, dan sebagainya, tidak lebih merupakan media / pelengkap (wasīlah) saja untuk mewujudkan tujuan utama dari pewahyuan al-Qur`an $(u s ̦ \bar{u} l) .{ }^{23}$ Menurut Darwazat, mengkaji perbedaan antara al-uṣūl dan al-wasāil sangatlah penting bagi para pembaca alQur`an, agar tidak kehilangan makna dari tujuan utama pewahyuan al-Qur`an. Dikotomi aluṣūl dan al-wasāil disarikan dari distingsi al-Qur`an berkaitan dengan ayat muhkamat dan ayat mutashābihāt. ${ }^{24}$ Ayat muhkamat merupakan ayat yang menunjuk pada sesuatu yang tidak berubah, seperti ayat tentang iman, kewajiban orang mukmin, hukuman dan ayat-ayat nāsikh. Sementara selebihnya merupakan ayat-ayat mutashābihāt. ${ }^{25}$ Ia mencontohkan bahwa suratsurat pertama al-Qur`an seperti al-Fātihah, al-A'lā (87), al-Shams (91), al-Lail (92), al-Ṭīn

\footnotetext{
21 Syuhada Subir, "Metodologi Tafsir al-Qur`an Muhammad Izzah Darwazat; Kajian Tentang Penafsiran AlQur`an Berdasarkan Tartib Nuzuly (Kronologi Pewahyuan)", (Tesis di UIN Syarif Hidayatullah Jakarta, 2009), 90.

${ }^{22}$ Ibid.

23 Ismail K Poonawala, Muhammad' Izzat Darwazat's Principles of Modern Exegesis, 230.

24 Q.S. al-Nisa`: 7.

25 Ismail K Poonawala, Muhammad 'Izzat Darwazat's Principles of Modern Exegesis, 231.
} 
(95), al-Qāri`ah (101), al-Takāthur (102), al-‘Aṣr (103), al-Ikhlāṣ (112), semuanya mengandung prinsip-prinsip dasar dan tujuan tersebut. ${ }^{26}$

Cara pandang Darwazat terhadap konsep al-uṣūl dan al-wasāil tersebut bisa kita telusuri salah satunya adalah ketika menjelaskan model penafsirannya terhadap kisah-kisah yang ada dalam al-Qur`an. Menurutnya, kisah-kisah kaum terdahulu yang disebutkan dalam al-Qur`an tidak sepenuhnya asing bagi bangsa Arab kala itu, karena komunitas suku Quraish Makkah saat itu sangat dekat dengan tradisi Injil. ${ }^{27}$ Bahkan di Madinah, dominasi suku-suku Yahudi juga sangat kuat, sehingga sejarah/cerita yang bersumber dari tradisi semitik sangat familiar di kalangan bangsa Arab. Fakta ini, lanjut Darwazat, meniscayakan sebuah cara berpikir bahwa kisah-kisah yang disebutkan dalam al-Qur`an tersebut tidak boleh diperlakukan sebagai model penuturan atau sebuah kajian pengungkapan sejarah, melainkan untuk menggambarkan moral, mengilustrasi suatu hal, mempertajam fokus perhatian dan mendukung pesan-pesan dasar pewahyuan al-Qur`an. ${ }^{28}$

Hal ini menjadi sangat fundamental untuk bisa memahami pesan-pesan dan prinsip alQur`an, tanpa harus kehilangan kisah-kisah yang lebih detail. Karenanya, pertanyaan tentang perbedaan cerita yang ada dalam al-Qur`an dan Injil yang dikemukakan oleh beberapa ahli menjadi tidak relevan. Ia menambahkan, bahwa jika banyak terdapat kepalsuan dalam ceritacerita tersebut, maka oposisi Nabi akan langsung mempersoalkanya dan menyerang alQur`an, bahwa mereka menolak kandungan cerita tersebut. ${ }^{29}$

Dalam kitab tafsir nya, juz VI, pandangan Darwazat mengenai posisi qașās al-Qur ’ān bisa kita ketemukan saat menguraikan Q.S. al-Kahfi:1-26. Dalam pembahasannya terhadap ayat-ayat yang mengisahkan tentang ashāb al-kahfi, Darwazat tidak "menginterupsi" dengan cara memotong urutan ayat-ayat tersebut (dari ayat 1 sampai dengan ayat 26) dengan penjelasan atau keterangan yang dikhawatirkan akan "merusak" kesatuan (tematik) dari beberapa ayat al-Qur`an yang hendak ditafsirkannya. Kembali ke kisah ashāb al-kahfi, walaupun Darwazat memberikan penjelasan yang cukup terperinci berkaitan dengan alur cerita ashāb al-kahfi, mulai dari tahun peristiwa, nama tokoh-tokohnya maupun tempat peristiwanya, namun penjelasan tersebut bukan merupakan inti dari penafsirannya terhadap

\footnotetext{
${ }^{26}$ Ibid.,

${ }^{27}$ Ismail K Poonawala, "Hermeneutika al-Qur`an: Mengenal Kitab al-Tafsīr al-Hadīth Karya Izzat Darwazat", terj. Faried A Saenong, Jurnal Studi Qur`an, Vol 1, No, 1, (Januari 2006), 135 - 136.

${ }^{28}$ Ibid.,

${ }^{29}$ Ibid.
}

80 AL-ITQAN,Volume 4, No. 1, 2018 

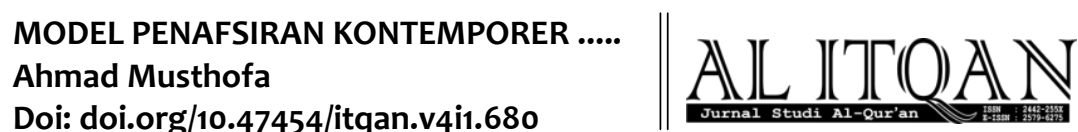

Q.S. al-Kahfi:1-26 tersebut. ${ }^{30}$ Namun sebaliknya, Darwazat mewanti-wantiagar kisah-kisah dalam al-Qur`an jangan sampai dijelaskan secara bertele-tele, ${ }^{31}$ sehingga menimbulkan banyak perdebatan, baik berkenaan dengan berapa jumlah pemuda kahfi tersebut (apakah 6, 7 atau bahkan 8? Atau malah 9?), berapa tahun mereka tertidur? Apakah tidur itu istilah majazi dalam al-Qur`an atau bagaimana? Di manakah peristiwa itu terjadi? dan seterusnya, di mana bagi Darwazat perdebatan demi perdebatan tersebut tidak produktif bahkan cenderung membelokkan para pembacanya semakin jauh dari pesan utama yang terkandung dalam setiap kisah-kisah yang dikemukakan oleh al-Qur`an. ${ }^{32}$

Bagi Darwazat, kisah ashāb al-kahfi tersebut (sebagaimana kisah-kisah isrāiliyyat lainnya) disinyalir merupakan kisah-kisah yang sudah cukup populer di kalangan Arab Quraish. ${ }^{33}$ Oleh karena itu, pesan dasar yang ingin disampaikan dalam kisah tersebut adalah sebagai penyemangat, pembelajaran, janji dan kabar gembira maupun suri tauladan bagi muslim minoritas di Makkah saat dimulainya risalah Islam yang dibawa oleh Nabi Muhammad SAW. Kebaikan, kebenaran biasanya memang di pihak minoritas, namun seiring perjalanan dan setelah melewati berbagai proses yang pahit, kebenaran akan mendapatkan kemenangan. ${ }^{34}$ Dalam pandangan Darwazat, pembuktian kebenaran historisitas peristiwa yang dikisahkan oleh al-Qur`an tersebutbukanlah menjadi urusan penafsiran, namun pesan fundamental yang dikandung dalam kisah tersebutlah yang menjadi fokus utama dalam pewahyuan al-Qur`an yang hendaknya terus digelorakan oleh setiap mufassir.

\section{Tafsīr al-Qur`ān bi al-Qur`ān}

Cara terbaik dan paling otentik dalam memahami al-Qur`an, mengetahui implikasi, intruksi serta situasi-kondisi pewahyuan al-Qur`an, adalah dengan menafsirkan al-Qur'an dengan al-Qur`an sendiri (yufassiru ba'ḍhū ba'ḍan). Metode ini sejauh mungkin bisa diterapkan tanpa harus mengabaikan kosa kata, gaya, perspektif, ordonansi, prinsip dan medianya. Hal ini menjadi penting karena akan membimbing pembaca dalam melawan berbagai spekulasi dan makna yang dipaksakan. Metode ini juga memungkinkan pembaca

\footnotetext{
${ }^{30}$ Sebagai seorang sejarawan, Darwazat memiliki kelebihan terutama dalam hal data-data historis berkaitan dengan hikayat ashāb al-kahfi, terutama data dan informasi yang bersumber dari tradisi semitik yang dalam Ulūm al-Qur'ān disebut sebagai isrāiliyyāt.

31 Muhammad 'Izzah Darwazat, al-Tafsīr al-Hadīth, 6:13.

${ }^{32}$ Ibid., 15.

${ }^{33}$ Darwazat menyuguhkan data bawa kepopuleran kisah-kisah isrāiliyyāt tersebut karena tidak sedikit kalangan Ahlu al-Kitab yang juga bermukim di sekitar Makkah, atau bisa jadi kisah-kisah tersebut didengar oleh para rombongan kafilah dagang para pedagang Quraish saat di daerah Syam dan sekitarnya yang memang menjadi sumber berkembangnya kisah-kisah isrāiliyyāt.

${ }^{34}$ Ibid.,
} 


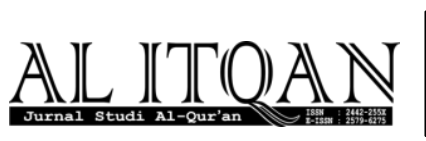

MODEL PENAFSIRAN KONTEMPORER .....

Ahmad Musthofa

Doi: doi.org/10.47454/itqan.v4i1.680

untuk membedakan mana tafsir yang benar dan mana tafsir yang salah. Darwazat juga menekankan bahwa hukum yang berlaku mesti dipertimbangkan ketika makna dan implikasi ayat-ayat khusus diragukan. ${ }^{35}$

Dalam kajian tafsir, khususnya al-Qur'an, istilah menafsirkan ayat dengan ayat sering dipakai dalam pengertian yang sama dengan pendekatan interteks - berangkat dari sudut pandang apakah al-Qur'an ataukah surat atau bahkan ayat yang dijadikan titik berangkat-, sebab pendekatan interteks memiliki dua kemungkinan cakupan, yaitu pertama, intertekstualitas dipahami sebagai padanan dari al-Qur'ān yufassiru ba'duhū ba'ḍan. Artinya, makna hubungan atau dependensi sebuah teks kepada teks yang lain masih berada dalam lingkup teks al-Qur'an itu sendiri. Kedua, hubungan antara sebuah teks dengan teks lain di luar teks tersebut. ${ }^{36}$ Istilah kedua inilah biasanya digunakan, terutama terkait hubungan antara al-Qur'an dan Bibel, sebagaimana yang dilakukan oleh Darwazat saat menafsirkan tentang menstrual Taboo dan Kontrol sosial perempuan, di mana Darwazat membandingkan ujaran teks tentang menstruasi perempuan dengan membandingkan antara ayat-ayat dalam al-Qur`an dengan teks tentang menstruasi yang ada di Bibel. ${ }^{37}$ Sedangkan al-Qur 'an yufassiru ba' ba'dan itu masuk dalam pengertian konteks yang pertama.

Di antara penafsiran dengan menggunakan pendekatan interteks dalam pengertian alQur`anyufassiru ba'ḍhū ba’ḍan adalah di saat Darwazat menafsirkan QS. al-Hajj: 32 - 33,

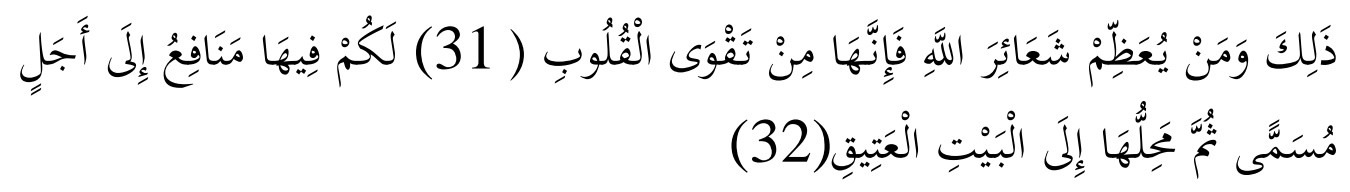

Ketika Darwazat menafsirkan kata شَعَائرَ اللَّهِ , yang diberi pemahaman sebagai kewajiban, perintah dan ketaatan terhadap ajaran agama Allah yang lurus, diperolehnya setelah ia mentautkan dengan dua ayat pada dua surat yang berbeda, yang menurutnya mampu menjelaskan makna dari kata tersebut, yaitu QS. al-Baqarah: 156,

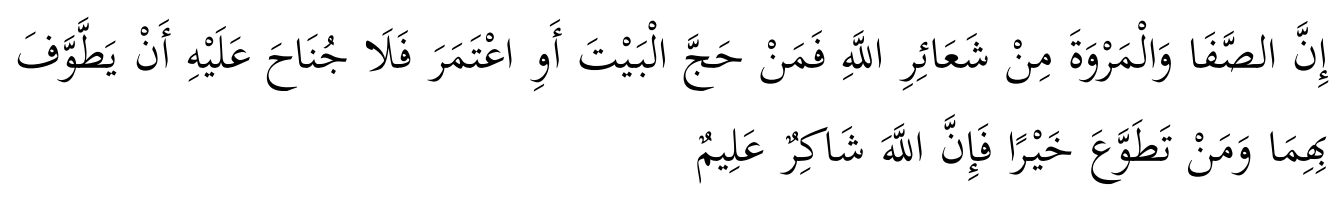

\footnotetext{
${ }^{35}$ Ismail K Poonawala, Muhammad 'Izzat Darwazat's Principles of Modern Exegesis, 234.

${ }^{36}$ Lenni Lestari, "Pendekatan Intertekstualitas Perspektif Muhammad 'IzzahDarwazat; Sebuah Kontribusi Dalam Menghadapi Masyarakat Multikultural”, Jurnal Al-Tafkir Vol. VII, No. 2 (Desember 2014), 29.

37 Lihat Leni Lestari, "Menstrual Taboo dan Kontrol Sosial Perempuan Menurut Muhammad 'Izzah Darwazat: Studi Intertekstualitas Terhadap al-Qur'an dan Bibel”, Jurnal SUHUF, Vol. 8, No. 2, (Juni 2015), 362.
} 
MODEL PENAFSIRAN KONTEMPORER .....

Ahmad Musthofa

Doi: doi.org/10.47454/itqan.v4i1.680

dan QS. al-Māidah:2:

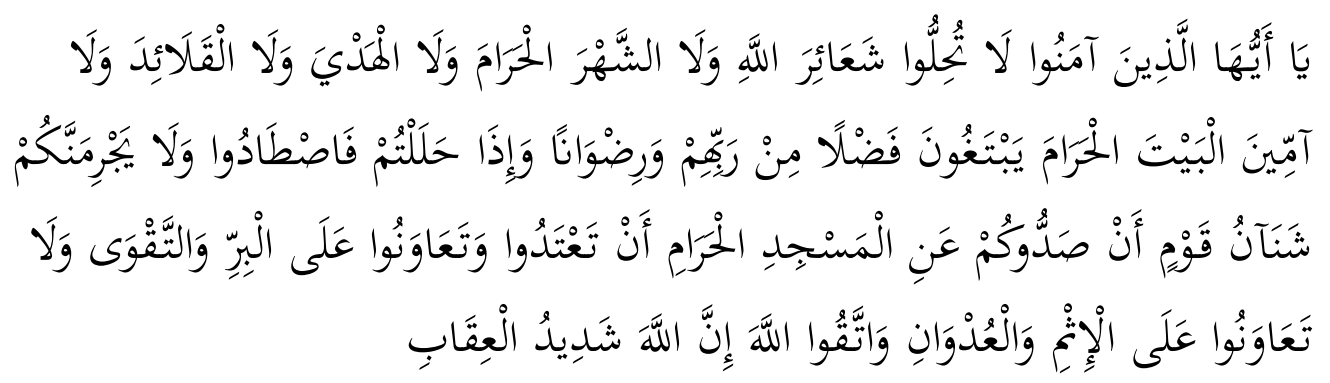

Dalam penafsirannya terahap QS. al-Hajj tersebut, ia menjelaskan bahwa sebelum Islam diwahyukan, bangsa Arab pra Islam memiliki tradisi mengorbankan hewan dengan cara dilukai sekedar mengeluarkan darah dari hewan sebagai tanda bahwa hewan tersebut sebagai hewan kurban. Tradisi ini disebut sebagai شععار dan شعيرة sedangkan hewan yang ditandai untuk kurban disebut شَعَائرِ

Namun dengan mentautkanya pada QS. al-Baqarah: 156, apalagi dengan penyebutan

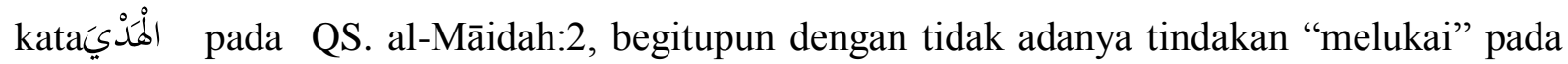
hewan yang akan dikurbankan maka penunjukan maknapun menjadi jelas, yaitu berkaitan dengan perintah-perintah dan seperangkat ritual yang wajib dijalankan saat menunaikan ibadah haji. ${ }^{38}$

\section{Susunan Kronologis dan Konteks (Asbāb al-Nuzūul)}

Berbeda dengan pandangan mainstream para mufassir, baik klasik maupun kontemporer, yang sangat memperhatikan posisi asbāb al-nuzūl dalam menafsirkan alQur`an, Darwazat justru mengkritisinya sebagai sebuah pendekatan tradisional. ${ }^{39}$ Ia menganggap bahwa rasionalisasi terhadap ayat tertentu terkadang tidak sesuai dengan konteksnya, karena itu menurutnya, penerapan asbāb al-nuz $\bar{u} l$ untuk kepentingan penafsiran al-Qur`an tidak boleh dilakukan secara sembrono. ${ }^{40}$

Asbāb al-nuzūl dalam pandangan Darwazat, tidak boleh dianggap sebagai satu-satunya sebab turunnya sebuah wahyu, namun hendaknya didudukkan sebatas penjelasan saja bahwa ada suatu rujukan al-Qur`an pada peristiwa-peristiwa yang terjadi sebelum ayat al-Qur`an diturunkan. ${ }^{41}$ Selain itu, Darwazat memandang bahwa riwayat asbāb al-nuzūl - meskipun

\footnotetext{
38 Muhammad 'Izzah Darwazat, al-Tafsīr al-Hadīth: al-Suwar Murattabatun Hasba al-Nuzūl, 7:98.

39 Ismail K Poonawala, Muhammad 'Izzat Darwazat's Principles of Modern Exegesis, 234.

${ }^{40}$ Ibid.

${ }^{41}$ Ibid.,
} 


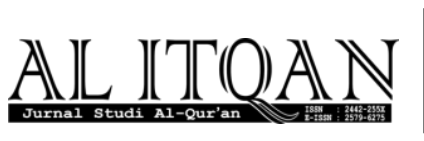

MODEL PENAFSIRAN KONTEMPORER .....

Ahmad Musthofa

Doi: doi.org/10.47454/itqan.v4i1.680

berstatus șạhḥ h- tidak lain hanyalah sebagai salah satu faktor eksternal yang dapat dipertimbangkan guna memahami makna ayat. Darwazat juga menambahkan dalam menganalisa asbāb al-nuzūl sebuah ayat al-Qur`an, seorang mufassir tidak hanya dapat menggunakan riwayat, akan tetapi mufassir juga dapat menggunakan posisi turun ayat dan konteks historisnya.

Agaknya pandangan Darwazat dalam hal ini sejalan dengan Aḥmad Khān yang menyatakan bahwa jalan yang paling selamat ditempuh dalam penulusuran asbāb al-nuzūl adalah mencari asbāb al-nuzūl dalam konteks kalam serta gaya al-Qur`an, setelah mempertimbangkan hal-hal mendasar yang dikemukakan dalam al-Qur`an. Demkian pula dengan Abū Zaid yang memandang asbāb al-nuzūl sebagai informasi historis sekaligus sebagai pertimbangan dalam penafsiran al-Qur'an. Fazlurrahman menjadikan asbāb al-nuzūl; baik mikro maupun makro sebagai informasi historis yang harus diketahui dan dijadikan pertimbangan dalam penafsiran. Dengan demikian, fungsi asbāb al-nuzūl di samping sebagai informasi historis juga sebagai pertimbangan dalam penafsiran al-Qur'an. ${ }^{42}$

Berbeda dengan pandangan Syahrur, yang menyatakan bahwa asbāb al-nuzūl hanyalah salah satu varian penafsiran yang bersifat particular-historis dan lokal temporal. Oleh karena itulah, menurut Syahrur, menjadikannya sebagaibagian dari Ulūm al-Qur'ān, merupakan sebuah kelemahan, sebagaimana juga menjadikan ilmu tajwīddan ilmu qirā'at sebagai bagian darinya. Sebab, sebenarnya ia masuk dalam lingkaran sejarah yang terbatasi oleh ruang, waktu dan pemeran pada saat itu. Oleh karena itulah, ia lebih tepat jika dijadikan sebagai bagian dari ilmu sejarah. ${ }^{43}$

\section{F. Kritik M Izzat Darwazat Terhadap Metode Penafsiran Lain}

Darwazat menambah deretan para mufassiryang sangat kritis terhadap beberapa tafsir modern yang memanfaatkan ayat-ayat tertentu untuk membidani dan mendukung teori-teori ilmiah. Corak tafsir ini kemudian dikategorikan sebagai tafsir'ilm. Munculnya beragam tafsir bercorak ilmiseringkali dihubungkan dengan tafsir karya Ṭantāwi Jauharī yaitu al-Jawāhir fì Tafsìr al-Qur 'ān al-Karīm yang dicetak pada tahun 1929 oleh penerbit Mu’assasah Muṣhaf

\footnotetext{
42 Sayyid Aḥmad Khān, "Principles of Exegesis," in Aziz Ahmad \& G.E. von Grunebaum (ed.), Muslim SelfStatement in India and Pakistan (Wiesbaden: Otto Harrassowitz, 1970), 34. Lihat juga Taufik Adnan Amal, Rekontruksi Sejarah al-Qur`an (Jakarta: Pustaka Alvabet, 2005), 101.

43 Syahrur, Naḥw Ușūl Jadīdah, 230.
} 

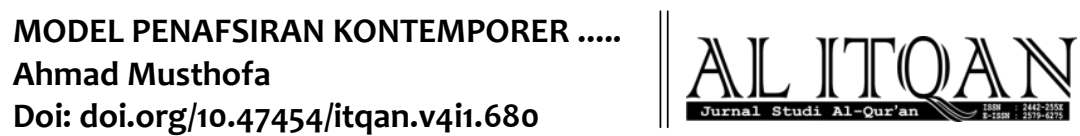

al-Bāb al-Halabi. Dalam tafsirnya tersebut, Ṭanțāwī dengan lantang mengajak umat Islam untuk menggalakkan kembali kajian sains. ${ }^{44}$

Dalam perkembangan selanjutnya, tafsir 'ilm ini menimbulkan pro dan kontra selain juga ada beberapa ulama tafsir yang memilih jalan tengah (moderat). Selain Darwazat, ada cukup banyak mufassiryang berpendapat kritis terhadap tafsir bercorak 'ilmi, di antaranya adalah al-Shāṭibi, Muḥammad Ḥusain al-Dhahābi, Bintu al-Shați, Șubḥ̄ al-Ṣāliḥ, Amīn alKhulli dan Mahmūd Shalțūt, yang secara terang-terangan mengekspresikan keberatan mereka akan penggunaan sains dalam menafsirkan al-Qur'an. ${ }^{45}$ Amīn al-Khulli misalnya, menyebutkan tiga aspek yang menjadi dasar penolakannya terhadap corak tafsir 'ilmi, yaitu : (1) aspek bahasa, yang mana penafsiran saintifik tidak kompatibel dengan makna katakata alQur'an. Hal itu dikarenakan perkembangan kata-kata Al-Qur'an secara eksplisit tidak bersinggungan dengan terminologi ilmu-ilmu sains, (2) aspek filologi, bahasa dan sastra bahwasanya al-Qur`an yang diturunkan di kalangan masyarakat Arab sebagai sasaran wahyu pada abad ke tujuh, tidak berisi informasi-informasi pengetahuan alam yang belum mampu dipahami oleh mereka, dan aspek ketidaksesuaian secara filologis ini dapat dilihat dari ketepatan makna pesan yang dibawa oleh Al-Qur`an, dan (3) aspek teologis, bahwasanya alQur'an merupakan kitab suci yang memuat misi pesan-pesan moral keagamaan, dan tidak bersentuhan dengan teori-teori kosmologis. Oleh karena itulah, al-Qur`an tidak boleh dipaksakan untuk diselaraskan dengan penemuan-penemuan di bidang keilmuan, seperti fisika, kimia, astronomi, biologi, yang mana semuanya ini bersifat relatif dan temporer. Tafsir saintifik ini, tentunya sangat dipengaruhi oleh perhatiannya yang sangat besar terhadap pendekatan sastra dalam menafsirkan al-Qur'an. Tafsir saintifik ini merupakan bentuk pemaksaan terhadap teks-teks al-Qur'an untuk diselaraskan dengan penemuan-penemuan ilmiah yang senantiasa berkembang dan berubah. ${ }^{46}$

Darwazat sendiri berpendapat bahwa mufassir dengan menggunakan ayat-ayat tertentu untuk menyokong teori ilmiah, telah melakukan kriminalisasi terhadap Islam dengan meremehkan karakter transenden al-Qur`an. Ia mengutip pernyataan Imam Ghazali : ${ }^{47}$

\footnotetext{
44 Annas Rolli Muchlisin dan Khairun Nisa, "Geliat Tafsir 'Ilmi di Indonesia Dari Tafsir al-Nur Hingga Tafsir Salman, Journal of Islamic Studies and Humanity, Vol. 2, No. 2, (Desember 2017), 239-257.

${ }^{45}$ Ibid., 244.

46 Muhammad Aminullah, "Hermeneutika Dan Linguistik Perspektif Metode Tafsir Sastra", Jurnal El-Hikam, Vol. IX Nomor 2 (Juli-Desember 2016), 334-335, diakses dari http://ejournal.kopertais4.or.id/sasambo/index.php/elhikam/article/view/2508/1850, pukul 23.55 WIB.

47 Ismail K Poonawala, Muhammad 'Izzat Darwazat's Principles of Modern Exegesis, 235-236.
} 
"Ada hal-hal yang diyakini oleh para filosof dan dianggap tidak bertentangan dengan doktrin agama. Karenanya mengimani Nabi dan Rasul bukan berarti menolak filusuf dalam hal-hal itu. Sebagai contoh, teori bahwa gerhana bulan terjadi ketika cahaya bulan menghilang karena karena interposisi bumi yang berada di antara bulan dan matahari. Bulan memperoleh cahaya dari matahari, sementara bumi berputar sendiri dengan dikelilingi oleh langit di segala sudut. Karenanya, ketika bulan berada pada bayang-bayang bumi cahaya matahari hilang. Contoh lainnya, gerhana matahari berani interposisi bulan antara matahari dan posisi manusia di bumi. Gerhana matahari terjadi ketika matahari dan bulan berhenti sejenak pada persimpangan titiknya, pada derajat yang sama."

"Kita tidak berkepentingan untuk menyangkal teori-teori ini, karena tidak ada tujuannya. Orang yang mengira bahwa menolak atau menyangkal adalah sebuah tugas religi, merupakan sebuah kejahatan terhadap agama. Segala hal ini terbentuk oleh fakta-fakta astronomis dan matematis yang eksak. Jika orang yang mempelajari teori ini - dan telah menyeleksi sejumlah data, dan berada dalam posisi untuk menentukan di mana gerhana bulan atau matahari akan terjadi, gerhana total atau biasa, berapa lama waktu terjadinya - diberitahu bahwa hal ini bertentangan dengan agama, maka agamanya akan goncang, tetapi kebenaran teori itu tetap ia yakini. Orang-orang seperti ini akan melakukan kejahatan terhadap agama lebih besar daripada musuh yang menyerang secara nyata. Karenanya sebagaimana pepatah : musuh yang bijak lebih baik dari teman yang jahat."

Pandangan serupa dari Darwazat juga diterapkan terhadap corak-corak penafsiran yang lain seperti tafsir fiqhi, tafsir falsafi maupun tafsir dengan pendekatan kalam. Ia mengkritisi sejumlah kaum teolog dan mazhab serta gologan sektarian yang memanfaatkan karya tafsirnya sebagai pegangan yang menguntungkan bagi doktrin kelompok mereka. ${ }^{48}$ Sementara mufassir lain sangat sibuk membongkar sesuatu yang mereka sebut dengan "misteri (al-asrār) dan simbol (al-rumūz)" yang disebutkan dalam al-Qur`an. Padahal menurut Darwazat pegetahuan akan kerahasiaan huruf-huruf tersebut tak lebih dari dugaan dan prasangka saja, namun kemudian tetap dituliskan mejadi sebuah penafsiran. ${ }^{49}$ Menurut M. Izzat Darwazat, tafsir yang paling baik adalah mengungkap petunjuk al-Qur`an terkait dengan pokok-pokok agama, hukum-hukum agama, dan pesan-pesan yang mengantarkan

\footnotetext{
48 M. Izzat Darwazat, al-Tafsīr al-Hadīth Tartīb Ṣuwar Hasaba al-Nuzūl: al-Qur'ān al-Majìd (Beirut: Dār alGarb al-Islami, 2000), 1:232.

${ }^{49}$ Ibid., 239.
} 

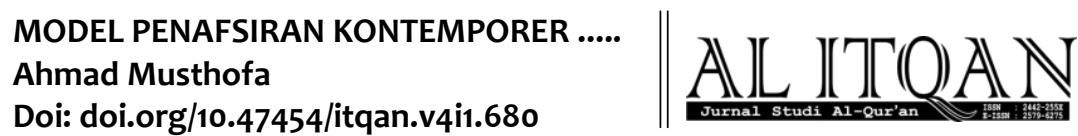

manusia kepada kebahagiaan hidup di dunia dan akhirat. Dan sebagai akibatnya, lanjut Darwazat, pesan dan tujuan utama al-Qur`an seringkali terabaikan, bahkan terlupakan. ${ }^{50}$

\section{G. Langkah-Langkah Penafsiran M Izzat Darwazat}

Hal yang unik sekaligus istimewa, Darwazat juga menjelaskan rincian langkahlangkah yang harus dilalui oleh seorang mufasir dalam muqaddīmah nya, ${ }^{51}$ yaitu:

1. Membagi ayat-ayat surah kedalam beberapa kelompok secara sempurna dan tepat, baik dilihat dari segi makna, langgam, tahapan turun ayat serta konteks ayat. Di mana setiap kelompok terdiri dari beberapa ayat ataupun dalam kelompok ayat yang panjang.

2. Menjelaskan (sharh) makna kata-kata atau kalimat asing dan baru yang terdapat pada kelompok ayat yang ditafsirkan, dengan penjelasan yang singkat, tanpa melakukan analisa kebahasan (lugawi), nahwu dan balagah (balāgī), jika hal itu dianggap tidak perlu atau penting.

3. Menjelaskan (sharhn) maksud inti kelompok ayat secara global (ijmālī), jelas, dan sederhana yang sesuai dengan kebutuhan, bila komposisi dan bahasa dari kelompok ayat tersebut telah dapat dipahami oleh orang yang berpaham sederhana.

4. Mengutip secara singkat riwayat-riwayat yang menunjukkan adanya korelasi antar ayat-ayat tersebut atau tentang sasaran yang dimaksudkan dan pendapat ulama mengenai maksud dan hukum yang diakndungnya, yang disertai dengan ulasan singkat.

5. Menyebutkan poin-poin hukum, prinsip, tujuan, peringatan dan bimbingan yang terdapat dalam kelompok ayat, baik dalam bentuk tashri', akhlak, aturan kemasyarakatan dan spiritual, serta membuat sebuah kesimpulan yang relevan dengan perkembangan hidup dan kecerdasan manusia.

6. Menghubungkan gambaran dan penjelasan pada kelompok ayat dengan biografi Nabi (sìrah) dan lingkungan hidup Nabi (al-bīah al-nabawiyyah). Karena menurut Darwazat tersebut sangat membantu dalam memahami situasi, perjalanan dan tahapan-

\footnotetext{
50 Ismail K Poonawala, Hermeneutika al-Qur`an: Mengenal Kitab al-Tafsīr al-Hadīth Karya Izzat Darwazat, 142.

51 Muhammad 'Izzah Darwazat, al-Tafsīr al-Hadīth: al-Suwar Murattabatun Hasba al-Nuzūl, 1:6-8.
} 
tahapan dakwah Nabi, dengan tujuan untuk melihat al-Qur’ân (maqāsid), baik yang berupa prinsip dasar (asās) maupun yang berupa media atau sarana (wasā ${ }^{\imath} l$ ).

7. Memberikan penekanan pada masalah yang bersifat media atau sarana (wasāiliyah) dan masalah yang bersifat pendukung (al-tad'imiyyah), bagi masalah pokok (usāsiyyah) al-Qur'an dalam pola (uslübiyyah) tertentu, seperti ta'qīb (susulan), ta'līl (sebab), tatmīn (menenangkan), taŝsbìt (meneguhkan), targīb (memotivasi), tarhīb (menakuti), taqrīb (mendekatkan), tamî̄il (memisalkan), tandīd (membandingkan)s, tanwīh (pujian), dan tazkkir (mengingatkan), dengan penejelasan yang singkat.

8. Menjelaskan kesinambungan ayat ataupun antara kelompok ayat, serta kesinambungan berbagai ungkapan al-Qur’ân yang sama konteks atau temanya. Hal bertujuan untuk menampakkan adanya kesatuan tema (al-nazm) Qur`an, serta menampakkan adanya keterkaitan dan keterikatan tema-tema, konteks, tujuan, serta instrument al-Qur`an. Dalam poin ini Darwazat memberikan perhatian khusus, karena menurutnya hal ini sangat membantu dalam memamhami dalālah al-Qur`an, ruang yang melingkupi turunnya wahyu, serta sejauh mana dimensi kandungannya.

9. Jika memungkinkan dan dianggap penting, memanfaatkan bantuan kata, struktur dan ungkapan al-Qur`an lainnya untuk menjelaskan tafsir, sharh, konteks, ta`wīl, dalālah, tujuan, pendukung, dan bukti sebuah ayat. Hal ini diperlukan bila terdapat ayat-ayat yang muṭlaq di satu tempat dan ayat-ayat pada tempat lainnya, atau 'àm dalam satu ayat dan $k h \bar{a} s$ dalam ayat lainnya, sebagaimana terdapat banyak kalimat yang lafaz nya berbeda akan tetapi memiliki makna dan tujuan yang sama. serta ditambah dengan bantuan riwayatriwayat yang relevan dengan konteks dan pendapat para mufassir.

10. Menghubungkan pembahasan tafsir ayat dengan rambu-rambu yang telah dipaparkan dalam kitab al-Qur'ān al-Majīd, agar tidak terjadi pengulangan pembahasan dan menghindari uraian yang panjang.

11. Mendeskrepsikan makna ayat dengan bahasa yang sederhana, mudah dipahami dan enak dibaca, serta menghindari penggunaan kata yang kurang familier, dan sulit.

12. Menjelaskan kata, makna, dan tema penting yang penyebutannya mengalami pengulangan dengan pembahasan yang memadai, terbebas dari cacat pada saat pertama kali muncul, kemudian menghubungkannya kembali pada penjelasan pertama, ketika kata atau istilah itu muncul pada pembahasan ayat setelahnya 
MODEL PENAFSIRAN KONTEMPORER .....

Ahmad Musthofa

Doi: doi.org/10.47454/itqan.v4i1.680

\section{H. Kesimpulan}

Penafsiran al-Qur`an M. Izzat Darwazat berdasarkan konsep tartīb al-nuzūli (kronologi turunnya ayat al-Qur`an) memang bukan sesuatu yang baru di bidang penafsiran, tercatat beberapa ulama sebelumnya sudah menggunakan model tartīb al-nuzūli. Namun, karya tafsir al-Qur'an M. 'Izzat Darwazat ini dinilai sangat istimewa, sebab penafsirannya dilakukan secara menyeluruh, mulai dari ayat yang pertama kali turun sampai dengan ayat yang terakhir turun. Selain itu, sentuhan-sentuhan hermeneutika yang juga diterapkan oleh M. Izzat Darwazat semakin mempertegas posisi pemikirannya di bidang tafsir al-Qur`an. Oleh karena itu, terlepas dari plus minus yang selalu ada dalam setiap karya, tafsir al-Qur`an karya M. Izzat Darwazat ini sangat layak untuk mendapatkan apresiasi setinggi-tingginya.

\section{DAFTAR PUSTAKA}

'Izzah Darwazat, Muḥammad al-Tafsīr al-Hadīth: al-Suwar Murattabatun Hasba al-Nuzūl. Damaskus: Dar Ihya`al-Kutub al-`Arabiyyah, 1960.

Amin Faris, Nabih. "The Arabs And Their Story”, MIDLE EAST JOURNAL, Vol. 8, No. 2, 1954.

Aminullah, Muhammad. "Hermeneutika dan Linguistik Perspektif Metode Tafsir Sastra", Jurnal El-Hikam, Vo. IX No. 2 Juli - Desember 2016.

Arikunto, Suharsimi. Prosedur Penelitian; Suatu Pendekatan Praktik. Jakarta: Rineka Cipta, 2014.

Hanafi, Hassan. "Dari Teks ke Aksi; Merekomendasikan Tafsir Tematik", jurnal STUDI QUR`AN, Vol. 1, Januari 2006.

-Hermeneutika al-Qur`an: Mengenal Kitab al-Tafsīr al-Hadīth Karya Izzat Darwazat, terj. Faried A Saenong, Jurnal Studi Qur`an, Vol. 1, No. 1, Januari 2006.

Julkarnaen, Muhammad. "Epistemologi Tafsir Ilmi Kemenag: Tumbuhan Dalam Perspektif Al-Qur`an dan Sains”, Jurnal Penelitian Keislaman, Vol. 10, No. 1, Januari 2014.

Lestari, Lenni. "Pendekatan Intertekstualitas Perspektif Muhammad 'Izzah Darwazat; Sebuah Kontribusi Dalam Menghadapi Masyarakat Multikultural, Jurnal At-Tafkir Vol. VII No. 2 Desember 2014. 
K Poonawala, Ismail. Muhammad 'Izzat Darwazat's Principles of Modern Exegesis; A Contribution Toward Qur`anic Hermeneutics, in APPROACH TO THE QUR`AN, ed. GR Hawting and Abdul Kader A Shareef. New York: Routledge, 1993.

Lestari, Leni. "Menstrual Taboo dan Kontrol Sosial Perempuan Menurut Muhammad 'Izzah Darwazat: Studi Intertekstualitas Terhadap al-Qur'an dan Bibel, Jurnal Suhuf, Vol. 8, No. 2, Juni 2015.

Muslih, Muhammad. "Arab Politics and the Rise of Palestinian Nationalism”, Journal of Palestine Studies, Vol. 16, No. 4 (Summer, 1987).

Rolli Muchlisin, Annas dan Nisa, Khairun. "Geliat Tafsir 'Ilmi di Indonesia dari Tafsir alNur Hingga Tafsir Salman”, Journal of Islamic Studies and Humanity, Vol. 2, No. 2, Desember 2017.

Syukri, Ahmad. Metodologi Tafsir al-Qur`an Kontemporer Dalam Pandangan Fazlurrahman. Jambi: Sulthan Thaha Press, 2002. 